\title{
地震時における斜面の簡易信頼性評価法 に関する基礎的研究
}

\author{
酒井 久和 1 ・奥村 誠 2 塩飽 拓司 3 ・香川 敬生 4 ・長谷川 浩一 5 ・ \\ 澤田純男6・多々納 裕一7 \\ 1正会員 広島工業大学教授 工学部建築工学科（干731-5193 広島市佐伯区三宅2-1-1） \\ E-mail: h-sakai@cc.it-hiroshima.ac.jp \\ 2正会員 東北大学教授 東北アジア研究センター（テ980-8577仙台市青葉区片平2-1-1） \\ E-mail: mokmr@m.tohoku.ac.jp \\ 3非会員 大林組 大阪本店建築事業部（干540-8584 大阪市中央区北浜東4-33） \\ E-mail: shiwaku.takushi@obayashi.co.jp \\ 4正会員 鳥取大学大学院教授 工学研究科（干680-8552 鳥取市湖山町南4-101） \\ E-mail: kagawa@cv.tottori-u.ac.jp \\ 5非会員 OYOインターナショナル＼cjkstart地震防災部（†112-0002 東京都文京区小石川1-1-17） \\ E-mail: hasegawa@oyointer.com \\ 6正会員 京都大学教授 防災研究所（干611-0011 京都府宇治市五尔庄） \\ E-mail: sawada@catfish.dpri.kyoto-u.ac.jp \\ 7正会員 京都大学教授 防災研究所（干611-0011 京都府宇治市五尔庄） \\ E-mail: tatano@imdr.dpri.kyoto-u.ac.jp
}

\begin{abstract}
本研究では，広域な道路ネットワークの地震による途絶確率を把握する目的で，斜面の崩壊確率の簡易 的な算定手法の提案を行った。国土交通省から提供を受けた六甲全山の地形データ，1995年兵庫県南部地 震の斜面崩壊領域データ, 地表面加速度データなどをもとに, 全斜面から補強斜面を除外した. 斜面の勾 配，平均曲率，地表面最大加速度を説明変数としたロジスティック回帰分析とともに，平均曲率を除いた 回帰分析も行った. その結果，斜面の勾配，地表面最大加速度に基づく斜面の崩壊確率の推定式が，兵庫 県南部地震における実崩壊状況と整合し，実用化の可能性を有することが確かめられた.
\end{abstract}

Key Words : logistics regression analysis ,slope, collapse ratio, earthquake, digital elevation model

\section{1. はじめに}

被害地震が発生するたびに，道路などのライフライン が被害を受けているが，2011 年東北地方太平洋沖地震, 2004 年新潟県中越地震では，多大な損傷を受けた東北 自動車道，関越自動車道が，早期に復旧したことが遠方 からの緊急車両の流入に大いに役立った。しかし，2011 年東北地方太平洋沖地震では，津波や地盤沈下が主要因 として道路が被災し，2004 年の新潟県中越地震，2007 年能登半島地震, 2008 年岩手・宮城内陸地震などの近 年の被害地震では，橋梁被害，斜面崩壊，道路盛土被害
により道路ネットワークが途絶し，孤立集落が発生した. これらの地震による道路ネットワークの途絶は，医療， 救出，緊急物資などの緊急車両の通行が制限され，地震 により被燚した住民がさらに厳しい状況下におかれるこ ととなった。そのため，各種自治体では道路ネットワー クを確保するために道路の耐震補強などの地震対策を強 化している例えば1),2),3).

しかし，今日の限られた予算内で道路の地震対策を行 うには限界があり，現在の多くの自治体で採用されてい る重要路線の耐震化の他に, 被災確率の小さなルートを 重点的に補強することが効果的であると考える. そのた 

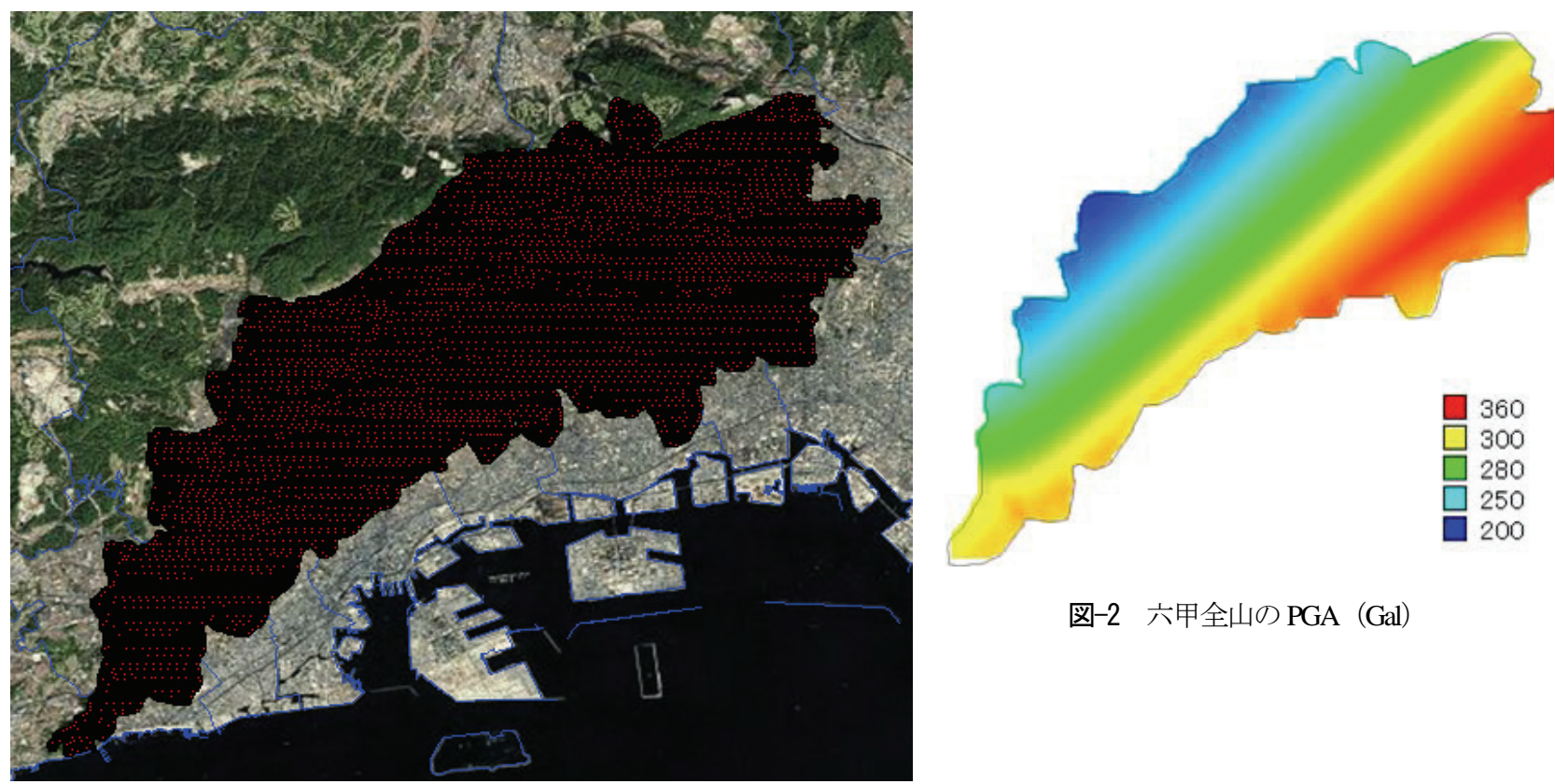

図-2＼cjkstart六甲全山の PGA（Gal）

図-1 検討対象領域（六甲全山）

めには，想定地震において，道路の被災確率を把握する 必要がある。

広域な道路盛土，斜面などの危険度を研究した事例は 少なくない. 本研究では，それらのうち，斜面を対象に 地震時の被災確率を評価するが，広域的に入手容易なデ 一タに基づいて斜面の地震時の危険性を評価する手法も 数種提案されている. 松岡, 翠川 ${ }^{4}$ は, 1974 年伊豆半島 沖地震, 1978 年伊豆大島近海地震, 1978 年宮城県沖地 震, 1984 年長野県西部地震, 1987 年千葉県東方沖地震 の 5 地震の被害データに基づいて, 斜面崩壊に大きな影 響を与えるものとして, 最大地動速度, 地盤の傾斜度, 地形分類, 堆積物の 4 要因（アイテム）を抽出し, 重回 帰分析により 3 段階の危険度を提案している. 内田ら5) は, 国土地理院の高密度な数值標高モデル（DEM：

Digital Elevation Model）を用いて，地震時の斜面崩壊の危 険度を 1995 年兵庫県南部地震の際の六甲山全山の被害 と，斜面勾配，平均曲率，最大加速度データとの関係か ら線形判別関数を用いた簡易手法を提案している.さら に，小山内ら ${ }^{6)} 2004$ 年新潟県中越地震，長谷川ら゙ 2007 年新潟県中越沖地震に適用し, 内田らの手法の有 用性を示している. しかし，内田らの線形判別関数では， そもそも判別值が正の值で崩壊, 負で非崩壊と判別され るもので, 崩壊斜面の 9割は崩壊と判定されるものの, 地震時の斜面崩壊率が小さいために，崩壊と判定されて いるものの中の非崩壊の斜面は 5 割余り存在し, 全体の 的中率は 49\%に留まっている. また，判別式から直接的 に崩壊率が得られるのではなく, 判別值と既往地震の被 害率の関係から斜面の被害を求めることになるため, 斜 面のフラジリティ評価関数は階段状の不連続性を示すこ とになる，そこで本研究では，斜面の崩壊，非崩壊の 2
值の質的な目的変数を, 被災確率としての量的変数とし て予測するロジスティックモデルで評価する.

\section{2. 検討方法}

\section{（1）検討データ}

本研究では, 内田らの兵庫県南部地震における六甲山 全斜面の地形，地表面最大加速度（PGA）データおよび 崩壊ポリゴンデータ5,8)を基に研究を進める。ただし，内 田らの平均曲率データには，99\%が - 0.03 0.03 の範囲内 にあるにもかかわらず，1.00 の值を示す特異なデータが 存在していたため信頼性の観点から除去した。まず，崩 壊ポリゴンデータから MapInfo を用いて崩壊, 非崩壊メ ッシュの判別を行う。この際, メッシュに崩壊領域が含 まれたものを崩壊メッシュと判定する. 次に，全斜面の 地形データには自然斜面と補強斜面のデータの両方が含 まれているため, 自然斜面の崩壊確率を求めるのに不要 な補強斜面を抽出する。 具体的には，兵庫県神戸県民局 神戸土木事務所公園砂防課の神戸市の六甲全山（灘区， 東灘区，中央区，長田区，須磨区，兵庫区，北区一部， 垂水区一部）における斜面補強工事記録9), 同課の阪 神・淡路大震災被害箇所図 ${ }^{10)}$, 地盤工学会の阪神淡路大 震災調査報告11)，Googlemap の衛星写真に基づいて補強 エリアを特定し, 全斜面データから除外する。ちなみに $10 \mathrm{~m} \times 10 \mathrm{~m}$ の全約 170 万メッシュのうち, 崩壊メッシュ は約 1 万 5 千, 崩壊メッシュは補強メッシュは 2,111 で あった. (図-1参照)

地震動データの PGA の平面分布を図-2に示す.この 地震動は, Fukushima and Irikura の断層モデル ${ }^{12)}$ に福島, 


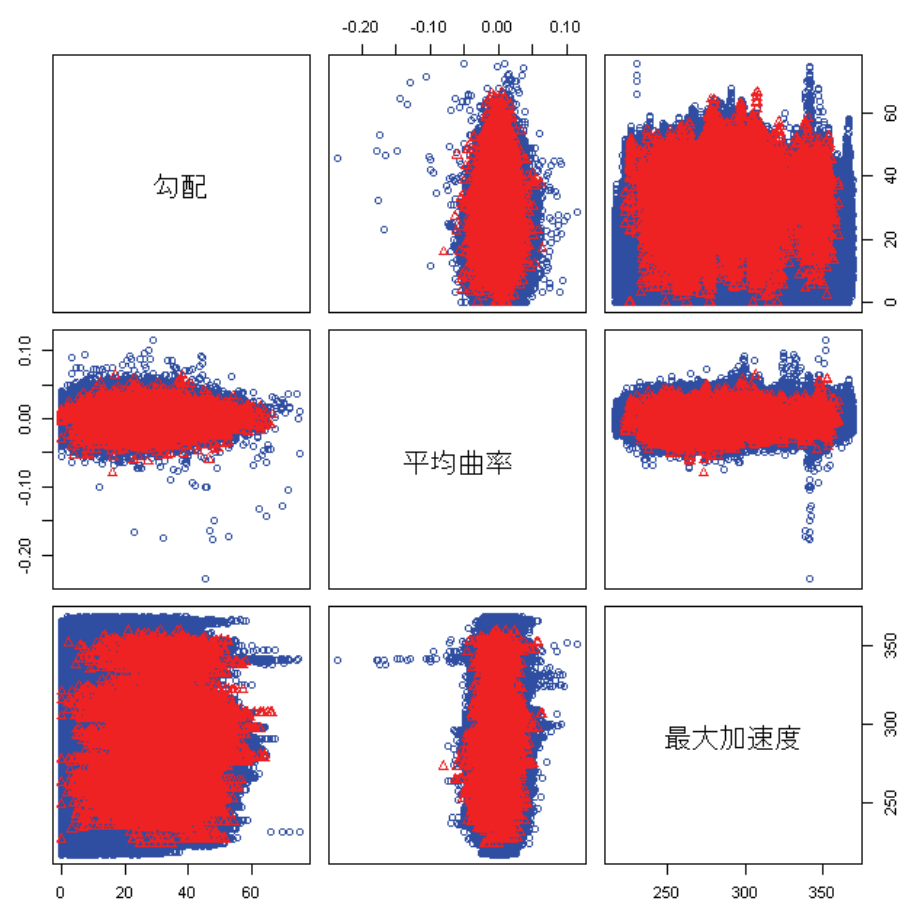

図-3 説明変数データの散布図 $(\bigcirc$ : 非崩壊, $\triangle$ : 崩壊 $)$

表-1＼cjkstart回帰分析ケースにおける説明変数

\begin{tabular}{|c|c|c|c|}
\hline & 勾配 & 平均曲率 & PGA \\
\hline Case1 & $\bigcirc$ & $\bigcirc$ & $\bigcirc$ \\
\hline Case2 & $\bigcirc$ & - & $\bigcirc$ \\
\hline
\end{tabular}

田中の距離減衰式 ${ }^{13)}$ ，司，翠川の破壊伝播効果 ${ }^{14)}$, 翠川 の地盤の増幅効果 ${ }^{15}$ を考慮されたものである. 図-2より, 六甲全山では PGA は約 200〜 400Gal の範囲内で北西方向 に PGA が小さくなる傾向があり，東側の東灘区，芦屋 市，西宮市の山間部で大きな PGA が作用していること が示されている.

検討データ (斜面勾配, 平均曲率, PGA) の散布図を 図-3に示す。図-3より，一見すると崩壊データが斜面勾 配が小さく, PGA が小さい領域でも分布しており，逆 に勾配が大きく，PGA が大きい領域でも非崩壊のデー タが存在することが分かる、これは本データに斜面の地 盤状態や集水地形状況など，斜面崩壊に影響が大きいと 考えられている要素が含まれていないこと，PGA が簡 易な距離减衰式で算定されていることに起因すると考え られる，しかしながら，本研究では，広域な斜面崩壊分 布を求めるにあたっては，前述のように容易に入手可能 なデータをもとにすることが実用面で重要であると考え， 上記の $3 つ の$ 説明変数を採用する.

\section{(2) ロジスティック回帰分析}

本研究のロジスティック回帰分析では，斜面の崩壊率 を斜面勾配，平均曲率，PGA の説明変数群で評価する. 評価式を式(1)に示す。ロジスティック回帰分析の詳細

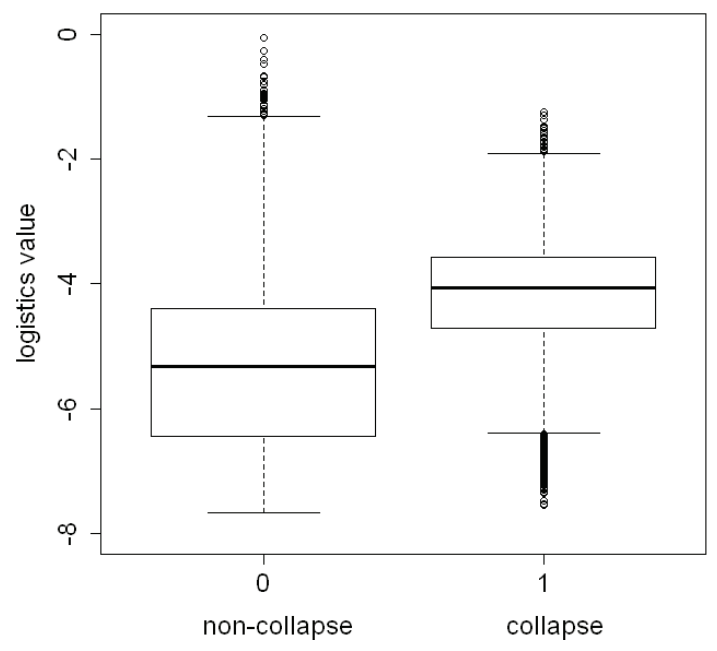

図-4 箱ひげ図（Case1）

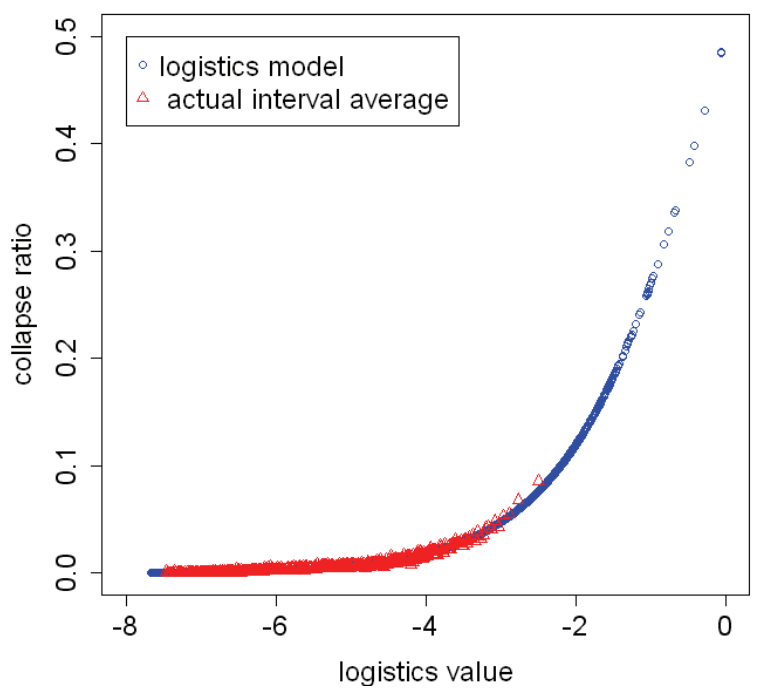

図-5 ロジット值と斜面崩壊率の関係（Case1）

については，文献16)を参照されたい.

$$
p(x)=\frac{1}{1+\exp \left\{-\left(b_{0}+b_{1} x_{1}+\cdots+b_{n} x_{n}\right)\right\}}
$$

ここに，p(x)は，崩壊確率， $b_{n}$ は偏回帰係数， $x_{n}$ は説明 変数を意味する.

説明変数として，内田らが地形要因の分析を経て採用 した斜面勾配，平均曲率，PGA だけでなく，平均曲率 を除いたケースについても分析を行う。ただし，統計解

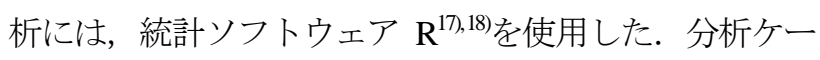
スを表-1に示す. 
表-2 ロジスティックモデルの偏回帰係数と有意水準 (Case1)

\begin{tabular}{|c|c|c|}
\hline & 係数 & 有意水淮 \\
\hline 定数 & -7.90 & 2e-16 \\
\hline 勾配 & 0.090 & $2 \mathrm{e}-16$ \\
\hline 平均曲率 & -6.70 & $1.25 \mathrm{e}-15$ \\
\hline PGA & 0.0019 & $1.01 \mathrm{e}-11$ \\
\hline
\end{tabular}

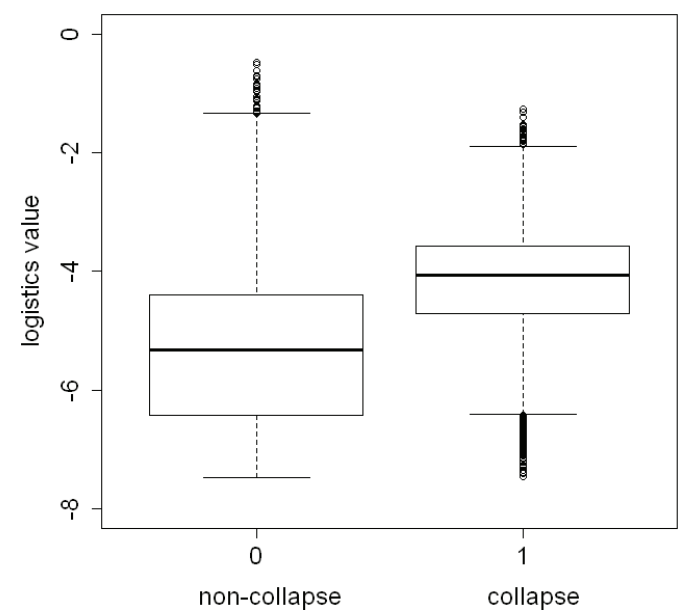

図-6 箱ひげ図（Case2）

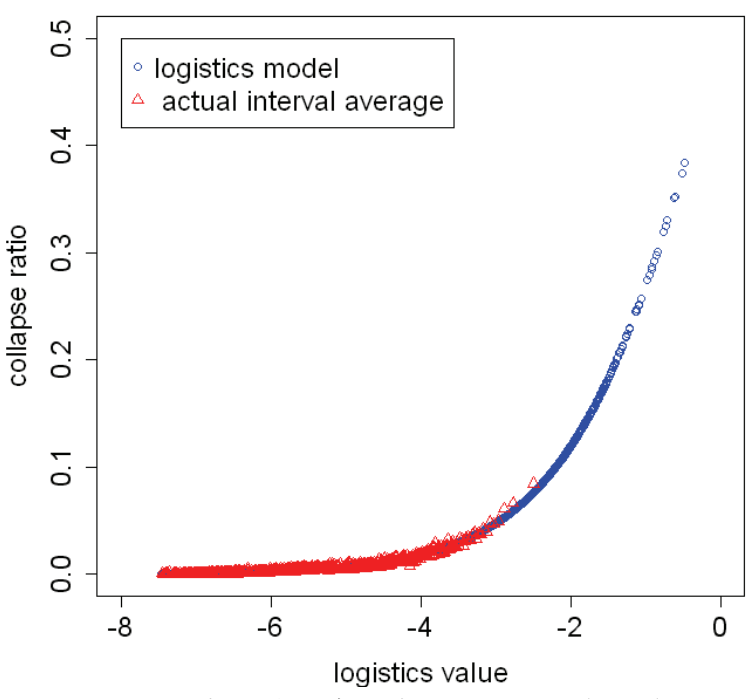

図-7 ロジット值と斜面崩壊率の関係（Case2）

表-3 ロジスティックモデルの偏回帰係数と有意水準 (Case2)

\begin{tabular}{|c|c|c|}
\hline & 係数 & 有意水準 \\
\hline 定数 & -7.89 & $2 \mathrm{e}-16$ \\
\hline 勾配 & 0.090 & $2 \mathrm{e}-16$ \\
\hline PGA & 0.0019 & $1.3 \mathrm{e}-11$ \\
\hline
\end{tabular}

\section{3. 分析結果}

\section{(1) Case1}

内田らの提案手法で採用された説明変数（勾配，平均 曲率，PGA）を用いて，ロジスティック回帰分析を行う.
得られた箱ひげ図，ロジット值と斜面崩壊率の関係，有 意水準を図-4，図-5，表-2に示寸．ただし，図-5中の赤 三角の実際の斜面の崩壊率は，ロジット值を大小順に並 べ替えた後 500 等分し，その範囲内での崩壊斜面数と全 斜面数との比であり，その際のロジット值はその範囲内 での平均值である.

図-4より非崩壊のデータで崩壊データよりもロジット 值が大きな外れ值は存在するが，非崩壊の第 3 四分位点 が崩壊の中央値より小さく, 両者の箱の重なりも小さい. すなわち非崩壊のデータの少なくとも $3 / 4$ は崩壊データ の中央值よりも小さなロジット值を示しており, 崩壊, 非崩壊データのロジット值の分布が大きく異なっている. また，図-5より，斜面崩壊のロジスティックモデルによ る推定式（図中の青丸が各データの算定値）が，実際の 被害率と比較して非常に高精度であることが分かる．た だし，ロジット值を小さい方から 200 分割したデータの 最大の崩壊率は約 1 割であり，また，プロット図-4の非 崩壊, 崩壊デー夕の外孔值から分かるように, 図-5の口 ジスティック值の相対的に大きなー 1 以上の領域は，全 て非崩壊のデータとなっている. 偏回帰係数については, 表-2より斜面勾配と PGA の係数が正の值となっており， 実現象と整合した符号となっている。平均曲率の偏回帰 係数は負であるが，これは水平，鉛直方向とも凸型の斜 面である方が崩壊率が高いことを意味する.

\section{(2) Case2}

平均曲率は地形の凹凸の指標として用いられ，DEM

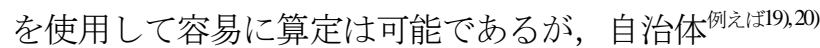
で広く使用されている危険個所のカルテには定量的な診 断項目に含まれていない，そのため, 地震時の斜面崩壊 に最も影響の強い要因として, 斜面勾配とPGAを用いて 回帰分析を行う. 得られた回帰分析結果と偏回帰係数, 有意水準を図-6，図-7，表-3に示寸。

図-6より, 非崩壊と崩壊のデータの分布状況は, Case1 と同様に非崩壊の第3四分位が崩壊の中央值より小 さく, 両者の箱の重なりも小さい. また, 図一にたおいて も，Case1と傾向はほとんど変わらず，ロジスティック モデルの推定式は実崩壊確率とよく整合している。 その 他，ロジスティック值を200分割したデータの最大の崩 壊率が1割程度であり, ロジスティック值がー 1 以上領 域は非崩壊データが占めることなど，Case1とほぼ同様 の傾向が見られる．また，表-3より，勾配，PGA，定数 の偏回帰係数がCase1と同值であり，これらのロジステ イック值に対する影響度が平均局率を説明変数として採 用しない場合と変わらないことが分かる.

前述のように, Case1とCase2の分析結果を比較して, 説明変数として平均曲率採用することによる効果が顕著 に見られないことから，本研究では少ない説明変数のケ 


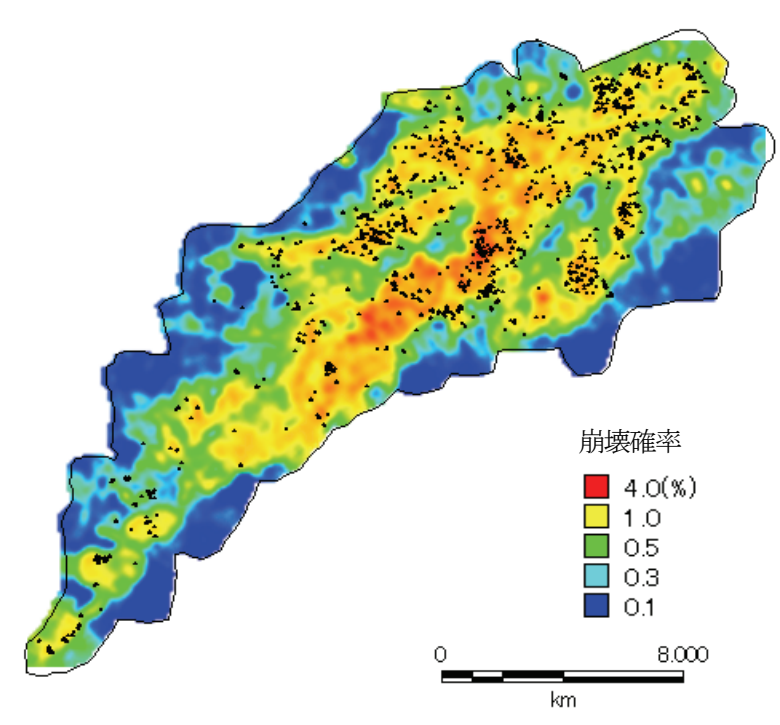

図-8＼cjkstart回帰分析の崩壊確率と崩壊箇所図（Case2）

ース, Case2（斜面勾配，PGA）を推奨する.

ここで，本推定手法の適用性を検証する目的で， Case2のリスク評価式により求められた崩壊確率を基に 分布図を作成し，兵庫県南部地震の斜面崩壊領域と照ら し合わせて，評価式の妥当性を確認する．斜面崩壊確率 分布マップと崩壊領域をプロットし図-8に示す.

図より，崩壊を示す領域がロジスティックモデルによ る崩壊確率の小さいエリアにはほとんど見られず，崩壊 確率の大きな暖色系のエリアに分布していることから, 推定結果が実被害と整合していると考えられる．ただし， 罒中の緑と寒色系のエリアについては，地震動指標が主 に距離減衰式に基づいて求められていることから，1\% 未満の精度を議論できないことを記しておく。

\section{4. まとめ}

本研究では，六甲山全地形データ，崩壊領域ポリゴン データ（多角形の面データ）を基に，斜面崩壊，非崩壊 を判別し，ロジスティックモデルを用いて，兵庫県南部 地震における六甲全山の自然斜面崩壊リスク評価方法の 検討を行った。 その結果，容易が入手可能な地形データ として斜面勾配と地表面最大加速度（PGA）を用いた下 記の評価式により, 兵庫県南部地震の崩壊エリアと整合 した結果が得られることが確かめられた。

$$
p=\frac{1}{1+\exp \{-(-7.89+0.09 A n g+0.0019 P G A)\}}
$$

ここに, $p:$ 崩壊確率

\author{
Ang : 斜面の公配(deg.) \\ $P G A$ : 地表面加速度 (Gal)
}

今後, 他の地域や地震被害についても本手法の妥当性を 検証し，想定地震に対する斜面の崩壊確率算定手法とし て，実問題に適用したいと考える.

\begin{abstract}
謝辞：本研究で使用した地形データ，斜面の崩壊デー 夕等は，近畿地方整備局六甲砂防事務所，国土技術政策 総合研究所危機管理技術研究センター砂防研究室から提 供を受けた。また，本研究は，土木学会リスク評価に基 づく道路構造物・ネットワークの耐震設計に関する合同 研究小委員会（多々納裕一, 澤田純男委員長）の研究活 動の一環として実施した. 委員各位には研究を進めるに あたり，貴重な意見，助言を頂いた。ここに関係各位に 謝意を表す.
\end{abstract}

\section{参考文献}

1) 鹿児島県：孤立化集落対策マニュアル，2007.

2) 青森県県土整備部：防災公共について, 2011.

3) 愛媛県土木部：社会資本総合整備計画，2012.

4) 松岡昌志, 翠川三郎: 国土数值情報を利用した地震時 斜面崩壊危険度予測, 日本建築学会構造系論文集, No.474, pp.59-66, 1995.

5) 内田太郎, 片岡正次郎, 岩男忠明, 松尾修, 寺田秀樹, 中野泰雄, 杉浦信男, 小山内信智 : 地震による斜面崩 壊危険度評価手法に関する研究，国総研資料，No.204， 2004.

6) 小山内信智, 内田太郎, 野呂智之, 山本悟, 小野田敏, 高山陶子, 戸村健太郎：既往崩壊事例から作成した地 震時斜面崩壊発生危険度評価手法の新潟県中越地震一 の適用, 砂防学会誌, Vol.59, pp.60-65, 2007.

7) Hasegawa, S., Dahal, R. K., Nishimura, T., Nonomura, A., and Yamanaka, M.: DEM-Based Analysis of EarthquakeInduced Shallow Landslide Susceptibility, Geotechnical and Geological Engineering, pp.419-430, Vol.27, Issue 3, 2009.

8) 国土交通省近畿地方整備局六甲砂防事務所 : 六甲山系 の斜面崩壊地判読図, 1995 1999.

9）兵庫県神戸県民局神戸土木事務所公園砂防課，神戸市 斜面補強工事記録

10)兵庫県神戸県民局神戸土木事務所公園砂防課，阪神 淡路大震㷋被災箇所図, 1997.

11)地盤工学会 : 阪神淡路大震災被害報告書, 1997 .

12)Fukushima, Y. and Irikura, K. : Attenuation characteristics of peak ground motions in the 1995 Hyogo-ken Nanbu earthquake, Journal of Physics of the Earth, No.45, pp.135146, 1997.

13)福島美光, 田中貞二 : 新しいデータベースを用いた最 大加速度の距離減衰式の改訂, 地震学会 1992 年秋季 大会講演予稿集, p.116, 1992.

14)司宏俊, 翠川三郎：統計的グリーン関数法に基づく地 震動最大振幅に対する破壊伝播効果による方位依存性 の評価, 日本建築学会構造系論文集, No.546, pp.4753, 2001. 
15)Midorikawa, S. : A Study of Site Amplification Effeets on Ground Motions in Santiago Chile, Tectonophysics, Vol. 218, No. 1-3, pp. 273-280, 1993.

16)丹後俊郎, 山岡和枝, 高木晴良：ロジスティック回帰 分析一SAS を利用した統計解析の実際一, 朝倉書店, 1996.

17)青木繁信 : Rによる統計解析，オーム社， 2009.
18)山田剛史，杉澤武俊，村井潤一郎：Rによる優しい統 計学, オーム社, 2008.

19)埼玉県：埼玉県地震被害想定調査報告書, 2011.

20)福岡県 : 福岡県地震に関する防災アセスメント調査報 告書, 2012.

(2012. 11.6 受付, 2013.2. 1 修正, 2013.2. 23 受理)

\title{
A FUNDAMENTAL STUDY ON SIMPLIFIED METHOD FOR CALCULATING EARTHQUAKE-INDUCED SLOPE COLLAPSE RATIO
}

\author{
Hisakazu SAKAI, Makoto OKUMURA, Takushi SHIWAKU, Takao KAGAWA, \\ Koichi HASEGAWA, Sumio SAWADA and Yuichi TATANO
}

We proposed a simplified method for calculating seismic slope collapse ratio in order to grasp disruption ratios of a boardband traffic network during a scenario earthquake. The used data are geography, slope failure areas and peak ground acceleration (PGA) etc. of whole Mt. Rokko during the 1995 Hyogoken nambu earthquake. We elimilated data on reinforced slope from them by scrutinizing construction reports etc. Logistic regression analysis using two data, angle of slope and PGA as the explanatory variable was conducted as well as that using three data, angle and average curvature of slope and PGA. The calculated ratios are correlated highly with areas of collapsed slopes during the earthquake. The result indicates the propsed method has a possibility for calculating earthquake-induced slope failure ratio. 